Tropical Journal of Pharmaceutical Research June 2016; 15 (6): 1293-1297

ISSN: $1596-5996$ (print); 1596-9827 (electronic) (C) Pharmacotherapy Group, Faculty of Pharmacy, University of Benin, Benin City, 300001 Nigeria.

All rights reserved.

\title{
Determination of borneol and other chemical compounds of essential oil of Dryobalanops aromatica exudate from Malaysia
}

\author{
Tian-Xin Le ${ }^{1}$, Anthony Siong-Hock $\mathrm{Ho}^{2}$, Siau-Hui Mah ${ }^{2}$, Tin-Wui Wong ${ }^{3}$, Hean- \\ Chooi Ong ${ }^{4}$, Patrick Heng-Meng Loh $^{5,6}$ and Yang-Mooi Lim ${ }^{1 *}$ \\ ${ }^{1}$ Department of Pre-Clinical Sciences, Faculty of Medicine and Health Sciences, Universiti Tunku Abdul Rahman, Lot PT \\ 21144, Jalan Sungai Long, Bandar Sungai Long, 43000 Kajang, Malaysia, ${ }^{2}$ School of Biosciences, Taylor's University, \\ Lakeside Campus, No.1, Jalan Taylor's, 47500 Subang Jaya, Selangor, Malaysia, ${ }^{3}$ Department of Pharmaceutics, Faculty of \\ Pharmacy, University, Teknologi MARA, Puncak Alam Campus, Bandar Puncak Alam, 42300 Selangor, Malaysia, ${ }^{4}$ Institute of \\ Biological Sciences, Faculty of Science, University of Malaya, 50603 Kuala Lumpur, Malaysia, ${ }^{5}$ Facullty of Sustainbility, \\ Environmental \& Life Sciences, Murdoch University, Loneragan Building, Perth, Western Australia 6150, ${ }^{6}$ School of Science \& \\ Technology, SIM University, 461 Clementi Road, Singapore 599491
}

*For correspondence: Email: ymlim@utar.edu.my; Tel: +60390860288; Fax: +60390191959

Received: 21 January 2016

Revised accepted: 4 April 2016

\begin{abstract}
Purpose: To determine borneol and other chemical compounds of essential oil derived from the exudate of Dryobalanops aromatica in Malaysia.

Methods: Exudate was collected from $D$. aromatica and subjected to fractional distillation to obtain essential oil. Gas chromatography-mass spectrometry (GC-MS) was performed to characterize the composition of the isolated essential oil.

Results: Essential oil (7.58 \%) was obtained with the highest yield (3.24\%) in the first $2 \mathrm{~h}$ of fractional distillation. Thirty compounds which accounted for $97.56 \%$ of total essential oil composition were identified by GC-MS, and they include sesquiterpenes (46.87\%), monoterpenes (31.05\%), oxygenated monoterpenes (16.76\%) and oxygenated sesquiterpenes (2.13\%). Borneol $(0.74 \%)$ was also detected in the essential oil.

Conclusion: Borneol and other terpenoid compounds are present in the essential oil of the exudate of D. aromatica.
\end{abstract}

Keywords: Exudate, Dryobalanops Aromatica, Fractional distillation, Essential oil, Gas chromatography-mass spectrometry, Borneol

Tropical Journal of Pharmaceutical Research is indexed by Science Citation Index (SciSearch), Scopus, International Pharmaceutical Abstract, Chemical Abstracts, Embase, Index Copernicus, EBSCO, African Index Medicus, JournalSeek, Journal Citation Reports/Science Edition, Directory of Open Access Journals (DOAJ), African Journal Online, Bioline International, Open-J-Gate and Pharmacy Abstracts

\section{INTRODUCTION}

D. aromatica is a large emergent tropical rainforest species which is recognised for its valuable timber, locally known as 'kapur', Borneo Camphor, Camphor Tree, or Sumatran Camphor. It can grow up to $60 \mathrm{~m}$ height with girth of $9 \mathrm{~m}$ [1]. It is distributed only in Peninsular Malaysia, Borneo and Sumatra [2]; and has been classified as critically endangered species in 2007. The genus Dryobalanops belongs to the Dipterocarpaceae family and is one of the two species that can be found in Peninsular Malaysia besides $D$. oblongifolia [2].

Although many ancient Chinese literatures have reported the premium source of borneol from $D$. aromatica, however, there are no scientific 
reports on the isolation of borneol from this plant $[3,4]$ particularly from the sources of exudates. Research on $D$. aromatica were mainly focused on the tree bark and there is limited information on the complete chemical profiling of the extracts or essential oil isolated from the exudates of $D$. aromatica.

Borneol is an expensive compound used in Chinese and Western medicine for many years and is an ingredient used in 65 traditional Chinese medicinal formulae [5]. In recent years, natural borneol were isolated from the leaves of Cinnamomum glanduliferum [6], Cinnamomum camphora [7] and Cinnamomum burmannii [8]. Besides natural borneol, borneol can be synthesized from turpentine oil or camphor as Borneolum syntheticum in the form of dl-borneol and iso-borneol, where the content of dl-borneol is greater than $55 \%$. However, synthetic borneol was shown to exert some toxic effects that due to the presence of iso-borneol and camphor [9]. This makes natural borneol especially d-borneol the valuable raw ingredient for medicinal purposes. Nevertheless, due to the high demand and production cost, there is a shortage for the source of natural borneol [10].

In view of the high distribution of $D$. aromatica in Peninsular Malaysia and the potential of $D$. aromatica as an alternative source of natural borneol; this study was conducted to determine the presence of borneol and other chemical composition in the essential oil extracted from the exudates of $D$. aromatica. Further downstream studies are focused on the wide range of potential biological activities of the essential oil and the isolated pure compounds, particularly on anti-cancer properties, namely cytotoxic and anti-tumour promoting activities.

\section{EXPERIMENTAL}

\section{Plant material}

Exudates of $D$. aromatica were collected from Commonwealth Forest Reserve, Selangor, Malaysia. Plant identification was authenticated by Professor Dr Ong Hean Chooi from University of Malaya, Malaysia. Voucher specimen (UTAR/LTX01/12) was prepared and deposited at Universiti of Tunku Abdul Rahman. Exudates were obtained either by natural secretion from the tree or by mechanical incision.

\section{Fractional distillation of exudates}

Exudates were subjected to fractional distillation in the presence of double distilled water for $2 \mathrm{~h}$. The vapour temperature was maintained at 80 $90{ }^{\circ} \mathrm{C}$. After cooling at room temperature for $2 \mathrm{~h}$, essential oil and distilled water collected at the collection bottle were separated and followed by another cycle of fractional distillation. The process was repeated until the yield of essential oil became minimal. The essential oil was then pooled and stored at $20^{\circ} \mathrm{C}$.

\section{Gas chromatography-mass spectrometry (GC-MS) analysis}

The essential oil was analyzed by Agilent 7890A/5975C GC-MS system equipped with HP5ms stationary phase column $(30 \mathrm{~m} \times 0.25$ $\mathrm{mm}$ internal diameter $\times 0.25 \mu \mathrm{m}$ film thickness) which composed of $5 \%$ phenyl $95 \%$ dimethylpolysiloxane. Helium was used as carrier gas and programmed at a flow rate of $1.0 \mathrm{ml} / \mathrm{min}$. The sample injection volume was $1 \mu \mathrm{L}$ with split ratio of $1: 10$. The initial oven temperature was programmed at $80{ }^{\circ} \mathrm{C}$ hold for $5 \mathrm{~min}$, then increased to $140{ }^{\circ} \mathrm{C}$ at $10{ }^{\circ} \mathrm{C} / \mathrm{min}$, hold for 0.5 min and increased to $300{ }^{\circ} \mathrm{C}$ at $30{ }^{\circ} \mathrm{C} / \mathrm{min}$ with final hold for $2 \mathrm{~min}$. Electron ionization system with ionization energy of $70 \mathrm{eV}$ was used. Injector and MS transfer line temperatures were set at 230 and $280{ }^{\circ} \mathrm{C}$, respectively. The MS system was operated in scan mode with a mass range of $50-800 \mathrm{~m} / \mathrm{z}$. Identification of compounds were achieved through the determination of retention indices (RI) with reference to a homologous series of n-alkanes (C8 - C20) and by NIST mass spectrum library matching.

\section{RESULTS}

\section{Yield of essential oil}

Through fractional distillation, different compounds were extracted based on their volatility. Less volatile compounds were separated first followed by more volatile compounds. The average essential oil obtained from the exudates of $D$. aromatica was $7.58 \%$ over $28 \mathrm{~h}$ of fractional distillation. The higest yield of essential oil was at the first $2 \mathrm{~h}$ of fractional distillation, which was $3.24 \%$; and the yield was decreased with increased number of cycle of fractional distillation.

\section{Composition of essential oil}

This is the first study reported on the chemical composition of essential oil extracted from the exudates of $D$. aromatica. Thirty compounds, 
which accounted for $97.56 \%$ of essential oil composition from the exudates of $D$. aromatica were identified using GC-MS analysis (Figure 1; Table 1). The essential oil consisted of monoterpenes and sesquiterpenes; where major compounds detected were $\beta$-caryophyllene (31.76\%), followed by $\alpha$-pinene $(21.49 \%)$, $\alpha$ caryophyllene (13.50\%), terpinen-4-ol (8.58\%) and $\alpha$-terpineol $(5.89 \%)$. Besides, $0.74 \%$ of borneol was detected.

\section{DISCUSSION}

Borneol is a bicyclic monoterpene that has been used in traditional Chinese medicine for many years as a premium ingredient to treat heart disease, coma and respiratory problems; improve digestive system; relieve pain; and promote relaxation [11]. In this study, borneol was detected in the essential oil of $D$. aromatica at $0.74 \%$. Besides, other compounds detected were $\beta$-caryophyllene (31.76 \%), $\alpha$-caryophyllene (13.50\%), a-pinene (21.49\%), terpinen-4-ol $(8.58 \%)$ and a-terpineol (5.89 \%) which accounted for $81.22 \%$ of the total essential oil. This study reported for the first time on the presence of $\alpha$-pinene, terpinen-4-ol and $\alpha$ terpineol as the major compounds from the exudates of $D$. aromatica. The finding of this study was different from Huang and Lu study, they reviewed that the exudates and essential oil of $D$. aromatica comprised of $d$-borneol, $\alpha$ caryophyllene, $\beta$-elemene, $\beta$-caryophyllene, asiatic acid, dryobalanone, erythrodiol and hydroxy-dammarenone II [3]. The synthesis of phytochemicals of a plant species can be affected qualitatively or quantitatively in response to environmental conditions; geographical variation; genetic factors and evolution; or physiological variations such as type of plant material, pollinator activity cycle, organ development and mechanical or chemical injuries $[12,13]$. The difference observed in the chemical composition of essential oil reported from the present study and Huang and Lu study might be due to geographical variation of plant species, which lead to difference in environmental and culture conditions.

In summary, the compounds detected in this study such as d-borneol, terpinen-4-ol, $\alpha$ terpineol, a-pinene and caryophyllene are terpenoid compounds, which is a large class of phytochemical well known for its anti-microbial, antiviral, anti-inflammatory and cytotoxic effects [14-20].Therefore, these terpenes compounds with potential biological activities should be subjected for further investigation.

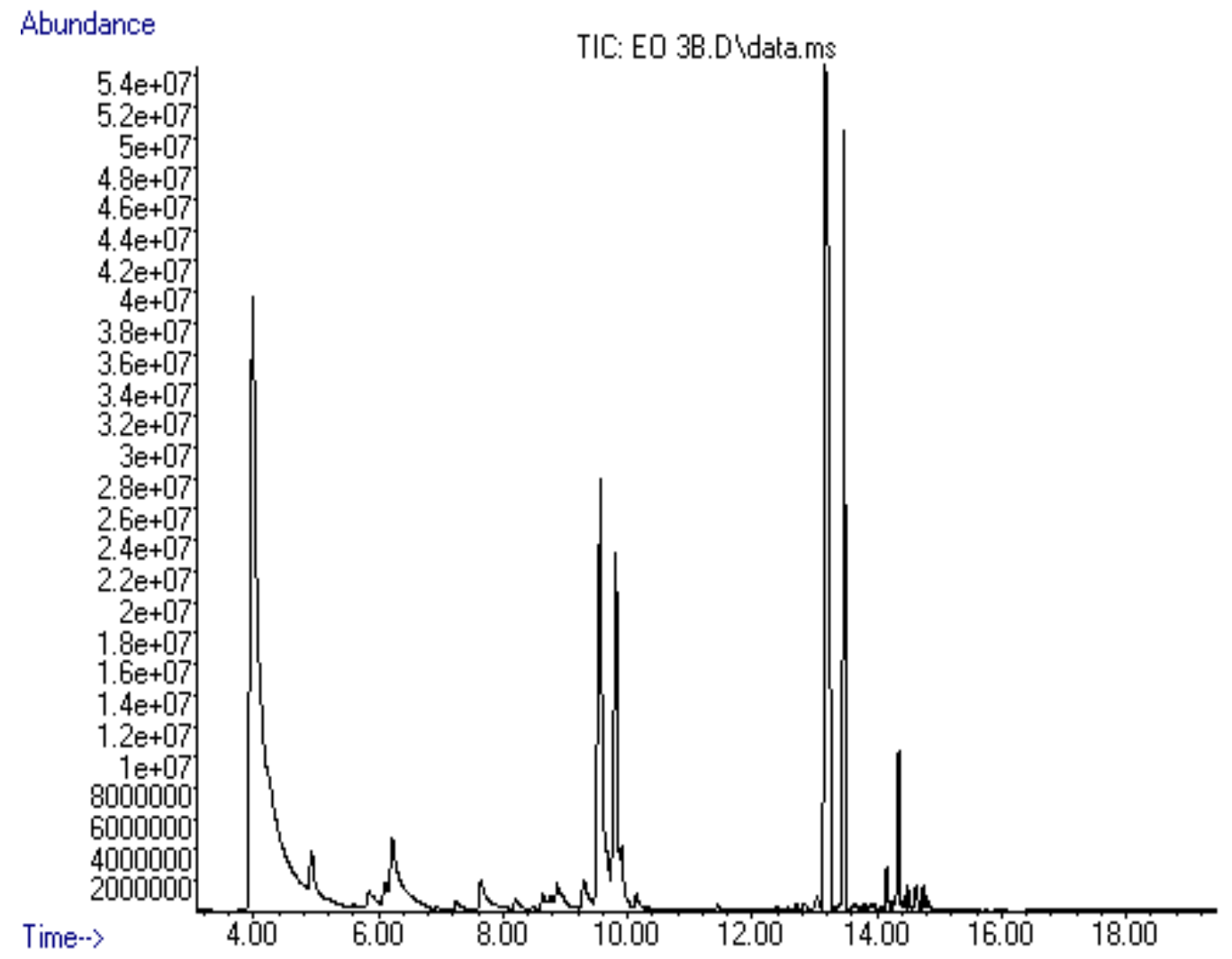


Figure 1: Total ion chromatogram of essential oil extracted from the exudates of $D$. aromatica following GC-MS analysis

Table 1: Chemical composition of essential oil extracted from the exudates of $D$. aromatic

\begin{tabular}{|c|c|c|c|c|c|c|c|c|}
\hline \multirow{2}{*}{ No. } & \multirow{2}{*}{ Compound } & \multirow{2}{*}{$\begin{array}{l}\text { Molecular } \\
\text { formula }\end{array}$} & \multirow{2}{*}{$\begin{array}{c}\text { RT } \\
(\min )\end{array}$} & \multirow{2}{*}{$\mathbf{R I}^{\mathrm{a}}$} & \multicolumn{3}{|c|}{ Sample $(n=3)$} & \multirow{2}{*}{$\begin{array}{c}\text { Content } \pm S D \\
(\%)\end{array}$} \\
\hline & & & & & 1 & 2 & 3 & \\
\hline 1 & $\alpha$-Pinene & $\mathrm{C}_{10} \mathrm{H}_{16}$ & 3.983 & 934 & 36.73 & 16.96 & 10.78 & $21.49 \pm 13.56$ \\
\hline 2 & $\beta$-Pinene & $\mathrm{C}_{10} \mathrm{H}_{16}$ & 4.928 & 979 & 1.42 & 0.84 & 0.56 & $0.94 \pm 0.44$ \\
\hline 3 & $\alpha$-Phellandrene & $\mathrm{C}_{10} \mathrm{H}_{16}$ & 5.597 & 1009 & - & 0.72 & 1.24 & $0.65 \pm 0.62$ \\
\hline 4 & 1,4-Cineole & $\mathrm{C}_{10} \mathrm{H}_{18} \mathrm{O}$ & 5.852 & 1019 & 0.64 & - & - & $0.21 \pm 0.37$ \\
\hline 5 & m-Cymene & $\mathrm{C}_{10} \mathrm{H}_{14}$ & 6.100 & 1029 & 0.55 & 0.27 & 0.26 & $0.36 \pm 0.16$ \\
\hline 6 & D-Limonene & $\mathrm{C}_{10} \mathrm{H}_{16}$ & 6.224 & 1034 & 4.15 & - & - & $1.38 \pm 2.40$ \\
\hline 7 & $\beta$-Myrcene & $\mathrm{C}_{10} \mathrm{H}_{16}$ & 6.231 & 1035 & - & 5.55 & - & $1.85 \pm 3.20$ \\
\hline 8 & $Y$-Terpinene & $\mathrm{C}_{10} \mathrm{H}_{16}$ & 6.934 & 1063 & - & 0.79 & 9.73 & $3.51 \pm 5.40$ \\
\hline 9 & (+)-4-Carene & $\mathrm{C}_{10} \mathrm{H}_{16}$ & 7.638 & 1092 & - & 0.93 & 0.41 & $0.45 \pm 0.47$ \\
\hline 10 & (+)-2-Carene & $\mathrm{C}_{10} \mathrm{H}_{16}$ & 7.652 & 1093 & 1.27 & - & - & $0.42 \pm 0.73$ \\
\hline 11 & (+)-Fenchol & $\mathrm{C}_{10} \mathrm{H}_{18} \mathrm{O}$ & 8.203 & 1118 & 0.28 & - & - & $0.09 \pm 0.16$ \\
\hline 12 & Terpinen-1-ol & $\mathrm{C}_{10} \mathrm{H}_{18} \mathrm{O}$ & 8.631 & 1139 & 0.36 & - & - & $0.12 \pm 0.21$ \\
\hline 13 & (-)-Camphor & $\mathrm{C}_{10} \mathrm{H}_{16} \mathrm{O}$ & 8.872 & 1151 & 1.03 & 0.99 & 1.14 & $1.05 \pm 0.08$ \\
\hline 14 & Borneol & $\mathrm{C}_{10} \mathrm{H}_{18} \mathrm{O}$ & 9.300 & 1172 & 0.84 & 0.79 & 0.58 & $0.74 \pm 0.14$ \\
\hline 15 & Terpinen-4-ol & $\mathrm{C}_{10} \mathrm{H}_{18} \mathrm{O}$ & 9.562 & 1185 & 10.64 & 5.81 & 9.29 & $8.58 \pm 2.49$ \\
\hline 16 & $\alpha$-Terpineol & $\mathrm{C}_{10} \mathrm{H}_{18} \mathrm{O}$ & 9.899 & 1202 & 7.96 & 5.89 & 3.81 & $5.89 \pm 2.08$ \\
\hline 17 & Verbenone & $\mathrm{C}_{10} \mathrm{H}_{14} \mathrm{O}$ & 10.141 & 1216 & 0.25 & - & - & $0.08 \pm 0.14$ \\
\hline 18 & Bornyl acetate & $\mathrm{C}_{12} \mathrm{H}_{20} \mathrm{O}_{2}$ & 11.444 & 1290 & - & 0.76 & 0.47 & $0.41 \pm 0.38$ \\
\hline 19 & Copaene & $\mathrm{C}_{15} \mathrm{H}_{24}$ & 12.713 & 1388 & 0.1 & 0.15 & - & $0.08 \pm 0.08$ \\
\hline 20 & $\alpha$-Farnesene & $\mathrm{C}_{15} \mathrm{H}_{24}$ & 12.816 & 1397 & 0.07 & - & - & $0.02 \pm 0.04$ \\
\hline 21 & $(-)-\beta$-Elemene & $\mathrm{C}_{15} \mathrm{H}_{24}$ & 12.864 & 1401 & - & 0.47 & 0.37 & $0.28 \pm 0.25$ \\
\hline 22 & Isocaryophillene & $\mathrm{C}_{15} \mathrm{H}_{24}$ & 13.044 & 1422 & 0.28 & - & - & $0.09 \pm 0.16$ \\
\hline 23 & $\beta$-Caryophyllene & $\mathrm{C}_{15} \mathrm{H}_{24}$ & 13.182 & 1439 & 21.23 & 37.96 & 36.09 & $31.76 \pm 9.17$ \\
\hline 24 & $\alpha$-caryophyllene & $\mathrm{C}_{15} \mathrm{H}_{24}$ & 13.478 & 1475 & 8.40 & 16.31 & 15.78 & $13.50 \pm 4.42$ \\
\hline 25 & Curcumene & $\mathrm{C}_{15} \mathrm{H}_{22}$ & 13.616 & 1492 & - & - & 0.87 & $0.29 \pm 0.50$ \\
\hline 26 & $(E)-\beta$-famesene & $\mathrm{C}_{15} \mathrm{H}_{24}$ & 13.802 & 1519 & - & 0.94 & 2.22 & $1.05 \pm 1.11$ \\
\hline 27 & $\alpha$-bergamotene & $\mathrm{C}_{15} \mathrm{H}_{24}$ & 13.864 & 1529 & - & - & 0.24 & $0.08 \pm 0.14$ \\
\hline 28 & cis- $\alpha$-bisabolene & $\mathrm{C}_{15} \mathrm{H}_{24}$ & 14.023 & 1554 & - & - & 0.11 & $0.04 \pm 0.06$ \\
\hline 29 & caryophyllene oxide & $\mathrm{C}_{15} \mathrm{H}_{24} \mathrm{O}$ & 14.354 & 1608 & 1.51 & 0.37 & 3.99 & $1.96 \pm 1.85$ \\
\hline 30 & humulene epoxide & $\mathrm{C}_{15} \mathrm{H}_{24} \mathrm{O}$ & 14.505 & 1638 & - & - & 0.52 & $0.17 \pm 0.30$ \\
\hline \multicolumn{2}{|c|}{ Monoterpene hydrocarbons } & & - & - & 44.12 & 26.06 & 22.98 & $31.05 \pm 11.42$ \\
\hline \multicolumn{2}{|c|}{ Oxygenated monoterpenes } & & - & - & 22.00 & 13.48 & 14.82 & $16.76 \pm 4.58$ \\
\hline \multicolumn{2}{|c|}{ Sesquiterpene hydrocarbons } & & - & - & 30.08 & 55.83 & 54.81 & $46.87 \pm 14.58$ \\
\hline \multicolumn{2}{|c|}{ Oxygenated sesquiterpenes } & & - & - & 1.51 & 0.37 & 4.51 & $2.13 \pm 2.14$ \\
\hline \multicolumn{2}{|c|}{ Others } & & - & - & - & 0.76 & 1.34 & $0.70 \pm 0.67$ \\
\hline \multicolumn{2}{|c|}{ Total identified } & & - & - & 97.71 & 96.50 & 98.46 & 97.56 \\
\hline
\end{tabular}

$R T$ : Retention time; ${ }^{a}$ Retention index determined using GC-MS with HP-5ms column in comparison to a series of homologous n-alkanes; "-": Not detected; SD: Standard deviation

\section{CONCLUSION}

The terpenes-rich compounds detected in the essential oil of the exudate of $D$. aromatica are of potential benefit to pharmaceutical, perfumery, aroma-therapeutic, cosmetic, detergent and food industries. Therefore, further downstream studies are currently focused on cytotoxic and antitumour promoting activities.

\section{ACKNOWLEDGEMENT}

The authors would like to express their deepest gratitude to Eu Yan Sang International Ltd
(Singapore) and Universiti Tunku Abdul Rahman for supporting and sponsoring this research (Vote nos. 4380/000 and 6200/L62).

\section{DECLARATIONS}

\section{Conflict of Interest}

No conflict of interest associated with this work.

\section{Contribution of Authors}

The authors declare that this work was done by the authors named in this article and all liabilities 
pertaining to claims relating to the content of this article will be borne by them.

\section{REFERENCES}

1. Gan KS, Choo T, Lim SC. Timber Notes - Medium Hardwoods I (Kapur, Kasai, Kelat, Keledang, Kempas). Timber Technology Centre (TTC), FRIM 1999; 11: 139258.

2. Ali RM, Koh MP, Michael M. Quantification of some components of the extractives of Dryobalanops aromatica obtained from different sources. J Trop Forest Sci 1991; 3: 367-371.

3. Huang WD, Lu WQ. The research development of borneol. China Pharm 2008; 17: 64-66.

4. Park TJ, Park YS, Lee TG, Ha H, Kim KT. Inhibition of acetylcholine-mediated effects by borneol. Biochem Pharmacol 2003; 65: 83-90.

5. Su J, Chen J, Liao S, Li L, Zhu L, Chen L. Composition and biological activities of the essential oil extracted from a novel plant of Cinnamomum camphora Chvar. Borneol. J Med Plants Res 2012; 6: 3487-3494.

6. Song YF, Luo JL. Study on preparation of high-purity natural d-borneol. Chemis Ind Forest Prod 2003; 23: 1114

7. Liu T, Gong L, Guo Y, Ren S, Yang L, Xiao B, Pan Q. Determination of $d$-borneol in the different parts of Cinnamomum camphora by GC-MS. Zhongguo Zhong Yao Za Zhi 2009; 34: 1692-1694.

8. Chen $L$, Su J, Li L, Li B, Li W. A new source of natural Dborneol and its characteristic. J Med Plants Res 2011; 5 : 3440-3447.

9. Hu LM, Fan GW, Gao XM, Zhang PL. Comparison on the influence of natural borneol and synthetic borneol on gastric mucosal barrier in rats. J Tianjin University TCM 2005; 24: 123-125.

10. Su J, Chen L, Li B, Li L. Extraction and Composition Analysis of Volatile Components in Leaves of Cinnamomun burmannii B1. J Food Science 2010; 31: 399-401.

11. Buchbauer G, Jager W, Jirovetz L, Meyer F, Dietrich $H$. Effects of valerian root oil, borneol, isoborneol, bornyl acetate and isobornyl acetate on the motility of laboratory animals (mice) after inhalation. Pharmazie 1992; 47: 620-622.

12. Figueiredo AC, Barroso JG, Pedro LG, Scheffer JJC. Factors affecting secondary metabolite production in plants: volatile components and essential oils. Flavour Frag J 2008; 23: 213-226.

13. Jayanthy A, Prakash KU, Remashree AB. Seasonal and geographical variations in cellular characters and chemical contents in Desmodium gangeticum (L.) DC. an ayurvedic medicinal plant. Int J Herbal Med 2013; 1 : 34-37.

14. Almeida, JR, Souza GR, Silva JC, Saraiva SR, Júnior RG, Quintans Jde S, Barreto Rde S, Bonjardim LR, Cavalcanti SC, Junior LJ. Borneol, a bicyclic monoterpene alcohol, reduces nociceptive behavior and inflammatory response in mice. Sci World J 2013; 2013 : 1-5.

15. Armaka M, Papanikolaou E, Sivropoulou A, Arsenakis M. Antiviral properties of isoborneol, a potent inhibitor of herpes simplex virus type 1. Antiviral Res 1999; 43: 7992.

16. Chen J, Li L, SU J, Li B, Chen T, Wong YS. Synergistic apoptosis-inducing effects on A375 human melanoma cells of natural borneol and curcumin. Plos One 2014; 9 : 1-9.

17. Legault J, Pichette A. Potentiating effect of $b$ caryophyllene on anticancer activity of a-humulene, isocaryophyllene and paclitaxel. J Pharmacy Pharmaco 2007; 59: 1643-1647.

18. Mondello F, Ricci M. Use of terpinen-4-ol as antimicrobial agent against bacteria of Legionella genus, Google Patents 2012.

19. Silva ACR, Lopes PM, Azevedo MMB, Costa DCM, Alviano CS, Alviano DS. Biological activities of a-pinene and B-pinene enantiomers. Molecules 2012; 17: 63056316.

20. Wu CS, Chen YJ, Chen JJW, Shieh JJ, Huang $\mathrm{CH}$, Lin PS, Chang GC, Chang JHT, Lin CC. Terpinen-4-ol induces apoptosis in human nonsmall cell lung cancer in vitro and in vivo. Evid Based Complementary Altern Med 2011; 2012: 1-13 